Socialist Studies: the Journal of the Society for Socialist Studies 5(2) Fall 2009: iv-viii

Copyright (C) 2009 The Author(s)

EDITORS'NOTE

\title{
Re-launching Socialist Studies
}

\author{
ELAINE COBURN \& CHAD D. THOMPSON \\ Co-Editors, Socialist Studies: the Journal for the Society of Socialist Studies
}

This issue marks the re-launch of the journal Socialist Studies. Beginning with this issue, and over the next few years, we seek to establish a stronger, more visible presence for the journal, making Socialist Studies an essential part of the debate among the critical left in Canada, and beyond. Capitalism is in crisis, once again. A few have more wealth than they could possibly use in a thousand lifetimes, while over a billion others live without enough to eat. More goods and services are being produced than at any other time in history, yet masses of human beings struggle to provide food, shelter and clothing for themselves and their families. The world is in need of alternatives and a space for dialogue around critiques and alternatives is vital, for new and established scholars, activists and others. Socialist Studies has an essential role to play, providing a place both for critical reflections on the capitalist world system and for discussions about a more equal, just world beyond capitalism.

This new step, aiming to increase the content, visibility and utility of Socialist Studies for critical scholars and activists on the left, is the latest development in the life of the journal. In May 2005, Socialist Studies: the Journal of the Society of Socialist Studies was established as a peerreviewed, interdisciplinary journal, replacing the Socialist Studies Bulletin, a more informal publication mainly featuring contributions by members of the Society for Socialist Studies. Sandra Rollings-Magnusson, a sociologist from Grant MacEwan University, served as the editor of Socialist Studies for the first nine issues, shepherding the journal through its early years and transition to a fully on-line journal in 2008. In this, she was supported by the energies of many committed volunteers, including the executive and 'lay' members of the Society for Socialist Studies.

In its first five years, contributing authors to Socialist Studies have drawn upon a wide variety of disciplinary perspectives to address many different subjects: globalization, neoliberalism, unemployment, processes of racialization, ecology, anarchism, citizenship, heterosexuality, social control, alternative globalization, colonialism, labour union politics, the 
New Democratic Party in Canada, and more. What the different contributions share are broad and diverse socialist perspectives, beginning with questions like: How are diverse social phenomena articulated with historical and contemporary forms of capitalism? What sorts of political struggles contribute to the transformation of human social relationships beyond capitalism, so that human needs are met and human capacities liberated?

\section{Our Vision for Socialist Studies}

As editors, we remain committed to Socialist Studies as a journal that welcomes contributions from all possible disciplinary perspectives, from both new and established scholars, from activists as well as academics, on a wide range of topics, from the family to ecology to the workplace to analyses of cultural events. Socialism offers distinctive 'takes' on all and any subjects, insofar as capitalism forms the context for social relationships in the contemporary context and historically, reaching back to the establishment of the capitalist world system over five hundred years ago. Yet, socialism is not any single, fixed theory with clear answers to every political injustice. We want Socialist Studies to initiate and sustain dialogues within the diversity of perspectives on the left: anarchisms; feminisms; social democracy, Marxisms, social ecology; and anti-colonial thought. We would like to emphasize the explicitly interdisciplinary, open character of Socialist Studies and the journal's role in participating and encouraging the widest possible terms of debate under the socialist banner.

\section{New Features of Socialist Studies}

As we re-launch Socialist Studies as a critical part of socialist debates in Canada and internationally, we are making changes to the journal. Some of these are apparent in the autumn 2009 issue, while others will be made for the spring 2010 issue:

- There are more full-length articles, an expanded book review section under the book review editorship of Murray Cooke and a substantive editorial to introduce each issue;

- Socialist Studies is now indexed with EBSCO Publishing, the Left Index and Wilson Social Sciences Full-text databases and is available through many Canadian universities; 
Socialist Studies: the Journal of the Society for Socialist Studies 5(2) Fall 2009: iv-viii

- Beginning with the spring issue, Socialist Studies will have a feature interview with an academic or activist. We are honoured that our first interviewee in the Spring 2010 issue will be well-known sociologist and long-time member of the Society for Socialist Studies William K. Carroll;

- Our website is undergoing transformation, seeking to be more reader-friendly and accessible. By spring, there will be a French mirror site as we strive to make the journal more genuinely bilingual. We are building reciprocal relationships with sister publications so that we have better links and are better known among the critical left community, especially in Canada.

We have also given the articles a new look and presentation, providing authors and readers with easier reference to publishing details, and increasing the ease of locating materials using online search engines. We hope these changes will increase the visibility and impact of Socialist Studies.

\section{Your Role in Re-Launching Socialist Studies}

As we work to establish Socialist Studies as a central reference for scholars, policymakers and activists in progressive circles in Canada and beyond, we will need your help. The left is not able to rely on the kinds of resources that are available to mainstream publications. Volunteer labour is vital to the left. Members of the Society for Socialist Studies, contributors and readers of Socialist Studies, and supporters of socialist ideas have always been necessary to existence and development of the journal. Your continued support of Socialist Studies is particularly urgent during this process of renewal. We ask you to consider some of the following actions:

- Contribute high-quality manuscripts of your own and let colleagues and students know we are an accessible forum for scholars, policy makers and activists seeking to reach other critical thinkers, with the advantage that we can publish relatively quickly and offer close editorial contact;

- Offer to guest-edit a special issue of the journal on a particular topic. In addition, we are eager to publish book reviews and reviews of special issues of other journals or cultural events;

- Ensure that your university library has us listed among its openaccess journals and contact us for a poster advertising our Fall 2009 and Spring 2010 issues; 
- Alert colleagues, students and friends to the re-launch of Socialist Studies by email, including our website address: www.socialiststudies.com .

Whether you are a long-time member of the Society for Socialist Studies or new to the journal, a young or established scholar or activist, please do not hesitate to contact us. Elaine Coburn and Chad Thompson may be reached at:

coburn@stanfordalumni.org

chad.d.thompson@gmail.com

We look forward to your suggestions for strengthening Socialist Studies, as we make the journal more visible, more relevant and ultimately an essential part of debates among progressive thinkers in Canada and internationally.

\section{Acknowledgements}

There are many, many hours of volunteer labour behind each issue of Socialist Studies. A few sentences are not adequate recognition of this work. Nonetheless, we would like to thank the Society for Socialist Studies for their financial, logistic and moral support. This notably includes the past executive of the Society for Socialist Studies, including past president Ken Collier and the current executive, including Norma Jo Baker, Debbie Dergousoff, Jerry Kachur, Colleen Lundy, June Madeley, Darrell McLaughlin and Jesse Vorst. Other members of the Society of Socialist Studies who have contributed to the development of the journal include Howie Chodos, past editor of the Socialist Studies Bulletin and Alice Vorst. We would like to acknowledge Sandra Magnusson-Rollins for editing Socialist Studies, including during times of terrible personal tragedy, as well as for her advice during the transition period. In addition, we thank Robert Sweeny for his help maintaining the Socialist Studies website. As we launch ourselves into our editorial tasks, we have particularly relied on the support of fellow board members William Carroll and Murray Cooke. The timely response of our many peer reviewers is greatly appreciated, especially given busy schedules: Socialist Studies could not function without this contribution. We are grateful to past members of the editorial board, Meir Amor, Gary Bieler, Tami Bereska, Christ Borst, Marie Campbell, Denise Doherty-Delorme, MaryAnn Farkas, Donald Fisher, Jamie-Lynn Magnusson, Robert Ratner, Robert Stirling, Jeffrey Taylor and the late Tom Middlebro and continuing editorial board members, Wayne Antony, 
William K. Carroll, Murray Cooke, Philip Hansen, Ian Hussey, Ross Klein, Patrice Leclerc, June Madeley, Stephen McBride, Dorothy Smith, and Gary Teeple. Finally, we would like to welcome new editorial board members, Sarah Amsler, Susan Dodd, Joseph Kaufert, Bryan Mitchell Evans and Ingo Schmidt.

The progressive left does not have easy access to financial resources, and socialist publications must operate largely at the margins of the mainstream academic and general media. Against this, we have a strong network of committed individuals who ensure that progressive left ideas continue to be debated. We appreciate your help with the journal and we look forward to working with you, as we create a stronger, more visible and more vital Socialist Studies. 